\title{
From Pétain to Pinochet: Raymond Aron, Henry Kissinger, and the Problem of Political Realism
}

\author{
Iain Stewart
}

\begin{abstract}
"Nobody has had a greater intellectual influence on me than Raymond Aron". Thus wrote Henry Kissinger in response to the death in October 1983 of the man he called "my teacher". ${ }^{1}$ Having first met in Paris during the early 1950s, Kissinger and Aron became friends while Aron held a visiting lectureship at Harvard in 1957. During the 1960s they entered into regular correspondence and usually arranged to meet whenever their paths crossed. After Aron published his book Paix et guerre entre les nations in 1962, Kissinger wrote to him that "I am reading the book with much discouragement, since I do not now know what there is to write about in the theory of international relations". ${ }^{2}$ Kissinger's review of the English translation for the New York Times was similarly glowing. ${ }^{3}$
\end{abstract}

After Kissinger entered public office in 1969, he maintained his correspondence with Aron, telling him that he should "never worry about impinging on my time" because "You are one of the very few people I always want to see". ${ }^{4}$ The continuation of this friendship was made easier by Raymond Aron's adherence to an intellectual ethic of responsibility based on a view of politics as something irreducible to morality that must be analysed from the statesman's perspective. But while Aron's coverage of American foreign policy during Kissinger's time in office was characteristically devoid of the moral outrage that this policy routinely provoked on the left, the two men would briefly fall out in the autumn of 1974 over the United States' role in the crisis that resulted in the partition of Cyprus and the collapse of Greece's military dictatorship.

Aron's unusually negative coverage of Kissinger's involvement in this crisis prompted an exchange of letters between the two friends on the need for authentic political realism to take ideals seriously. ${ }^{5}$ During the course of this correspondence, Aron's critique of Kissinger expanded beyond his role in the Cyprus crisis to encompass American involvement in the Chilean coup of September 1973. Yet here there was a disparity between Aron's published commentary, which at first did not implicate the United States and minimised the threat that Pinochet's regime posed to Chilean democracy, and his 
private concerns as expressed in his letters to Kissinger. This correspondence is of interest partly because it reveals some of the limitations of Aron's theory of international relations when applied to international crises in the real world. But it also provides an opportunity to re-consider the origins and implications of Aron's intellectual ethic of responsibility and the philosophically idealist form of political realism that informed it.

Aron's arrival at political maturity is generally considered to have entailed his wholesale rejection of the naïve idealism that allegedly characterised his politics as an undergraduate at the École normale supérieure in the late 1920s. Yet this was far from the case. Aron's commentators have accepted at face value his dismissal of his earliest political engagements in his various autobiographical works. In doing so, they overlook the fact that Aron's initial politicisation took place in the same intellectual circles from which French forms of fascism would emerge in the mid-1930s. Although he rejected the fascist turn later made by some of his acquaintances in the heterodox socialist and radical organisations in which he participated as an undergraduate, Aron was broadly sympathetic to their critique of French 'decadence', and by the late 1930s he was willing to tolerate the installation of a military dictatorship as an emergency solution to the crisis of republican democracy in France. Four decades later, the resurgent memory of France's interwar crisis of democracy, and its attendant demands for new forms of political realism, would substantially inform Aron's responses to the crises in Chile and Cyprus.

\section{From naïve idealism to mature realism: the consensus view of Aron's early intellectual development}

Scholarship on Raymond Aron routinely emphasises Aron's exceptionality in relation to his French intellectual contemporaries. His resistance to the 'totalitarian temptation' is

often cited as evidence for this. Unlike some of his more celebrated peers, Aron saw clearly and early the threats posed by National Socialism and Soviet communism and was never tempted to become an apologist for either regime. But this clear-sightedness is usually seen to be indicative of a more fundamental quality of Aron's thought: this is the notion that Aron was exceptional because he was a "genuinely political" thinker. This status has often been illustrated with a quotation from the television interviews that were published in 1981 
as Le spectateur engagé. Asked to explain his view that French intellectuals generally "refuse to think politically", Aron replied that:

It means two things. First, they prefer ideology, that is, a rather literary image of a desirable society, rather than to study the functioning of a given economy, of a liberal economy, a parliamentary system, and so forth. And then there is a second element, perhaps more basic: the refusal to ask the question someone once asked me: "If you were in the minister's position, what would you do?"6

In addition to defining his intellectual ethic in contrast to the alleged political irresponsibility of his peers, Aron also contrasted it with his own early politics, which he summarised as "vaguely socialist" and "passionately pacifist". It was during the three years he spent in Germany between 1930 and 1933, he repeatedly argued, that "I became conscious of the world. In other words, I completed my political education. [...] In 1933, I came back to France an adult". ${ }^{7}$ Aron understood his arrival at political adulthood as a rejection of the moralising and ideological tendencies that he associated with the progressive political milieu to which he had belonged as a student at the École normale supérieure between 1924 and 1928. Here again, Aron's commentators have tended to follow his lead. ${ }^{8}$ Aron's biographer, Nicolas Baverez, has written of "the depth and rapidity of the reversal of his values and prejudices" as a result of his time living in Cologne and Berlin. ${ }^{9}$ More recently, Aurelian Craiutu has remarked that "For Aron, the three years he lived in Germany between 1930 and 1933 were an eye-opening experience that constituted his real political education". ${ }^{10}$ Henceforth Aron would be committed to "thinking 'politically' as opposed to thinking 'ideologically", or, put differently, to "thinking politically in a non-sentimental, objective and non-moralising way". ${ }^{11}$

Evidence for the generally accepted view of Aron's intellectual development can be found in some of his writings from the 1930s. In his memoirs, Aron attributed particular importance to two texts published in February 1933, towards the end of his time in Berlin. In one of these, his first philosophical critique of pacifism, Aron wrote that "The political problem is not a moral problem", while in the second, an open letter to the personalist 
journal Esprit, he announced that "I am no longer on the right or the left", before remarking that "If one wants to think or act in the political domain, above all it is necessary to take the world as it is" and to reject "ready-made ideologies". ${ }^{12}$ Both these articles were prompted by Adolf Hitler's appointment as Chancellor the previous month.

It would indeed be a mistake to understate the importance of Aron's German years to his intellectual ethic of responsibility. While his first-hand observation of the rise of National Socialism led Aron to abandon the pacifism that had largely defined his earlier politics, it was his encounter with the work of Max Weber that gave him an acute sense of the irreducibility of politics to morality and "the responsibility of everyone, not so much for his intentions as for the consequences of his choices". ${ }^{13}$ This encounter with Weber informed Aron's break with his former mentor Alain (Emile Chartier), whose pacifism and theory of the citoyen contre les pouvoirs inspired a generation of French normaliens. ${ }^{14}$ For Aron, Alain's view of war as the supreme evil to be avoided at all cost exemplified the idealistic ethic of conviction that Weber had critiqued as liable to result in consequences diametrically opposed to the values it defended. ${ }^{15}$ Aron further distanced himself from Alain in an article on the economic policy of the Popular Front published in 1937. Here he set out a thinly veiled critique of the Comité de vigilance des intellectuels antifascistes established by Alain, the physicist Paul Langevin and the ethnographer Paul Rivet in 1934. "Intellectuals", Aron wrote, "should have a competent grasp of economics, diplomacy, [and] politics" if they want to intervene in political debates where, more often than not "justice is less at stake than effectiveness"; however, he went on, "the masses who place their trust in them are unaware that such an illustrious physicist, such a celebrated writer, such a renowned ethnologist know no more than the man in the street about the conditions of economic recovery". ${ }^{16}$

Whereas Alain implored his readers to "never believe what a politician says", from the mid-1930s onwards Aron claimed always to have approached political problems from the perspective of the politician. ${ }^{17}$ Thus it is true that Aron's adoption of this posture of "statesmanlike prudence", ${ }^{18}$ which has drawn the admiration of many of his commentators, required him to break with the teachings of Alain, whose influence on the early Aron is well known. Nevertheless, the notion that Aron's early intellectual development can be adequately summarised as a movement from youthful idealism to mature realism taking 
place between 1930 and 1933 remains problematic. On this view, Aron's earliest political engagements have nothing to tell us about the 'mature' Aron except that it was necessary for him to reject them to arrive at political adulthood. Yet an aspiration towards the philosophically idealist brand of political realism to which Aron referred in his correspondence with Kissinger can in fact be traced back to some of Aron's very earliest writings and political engagements.

\section{Raymond Aron's undergraduate politics revisited}

An examination of the student associations to which Aron belonged as an undergraduate calls the generally accepted view of his intellectual development into question. These were the École normale supérieure's Groupe d'étudiants socialistes, an organisation with close ties to Marcel Déat's anti-Marxist, revisionist wing of the SFIO, and the Groupement universitaire pour la Société des Nations, where Aron socialised with members of the heterodox 'young Turks' group within the Radical Party, such as Bertrand de Jouvenel and Alfred Fabre Luce. The heterodox radicals and socialists in both of these organisations explicitly presented themselves as "realists" challenging the ideological dogmatism of their respective party leaderships. ${ }^{19}$ Yet the "realism" propounded from within these overlapping milieux was one that explicitly rejected the realist-idealist distinction as a false dichotomy; realism and idealism were conceived as "two sides of the same medal", the former being "a logical consequence of an idealism that tends towards action and wants to express itself through action". ${ }^{20}$

Although Aron was a fairly peripheral figure in both the GES and the GUSDN, the views expressed in some of his earliest publications do bear the mark of his involvement with these associations. This is true, for instance, of Aron's first published article, in which he complains of the SFIO leadership's "mental enslavement" to outdated concepts like class struggle and the dictatorship of the proletariat, arguing for "a sense of realities to

displace the cult of outdated formulas". ${ }^{21}$ Remarks like these indicate that some of the defining themes of Aron's 'mature' political thought were actually present in his very earliest writings. To take a second example, his open letter to Esprit in the wake of Hitler's rise to power is typically cited as signalling a decisive turning point in his political 
development, but reading this text in the light of Aron's involvement with the "realist generation" of the GUSDN circle makes it appear more as a continuation of his earlier politics than a radical break:

Realist politics is not in my eyes a simple manner of envisaging such and such a problem. It expresses a spiritual will. ... Since lucidity is the first law of the mind, I am not returning to materialism. But the idea can only claim to be effective if it expresses the necessities of the moment and, without pity for facile beliefs, specifies the route suggested by reality. To accept this politics without illusions is not a betrayal, it is seriously to think through our condition. ${ }^{22}$

The earliest debates over political realism to which Aron contributed date from the late 1920s and were more concerned with the responsibilities of public intellectuals than they were with international relations theory. Aron's allusion to intellectual betrayal in the above passage gestures to La trahison des clercs (1927), Julian Benda's manifesto for an "idealist" form of intellectual engagement exclusively in defence of universal values. Benda defined his "idealism" against the "realism" of those intellectuals who intervened on behalf of specific national or class interests. ${ }^{23}$ His polemic served as a catalyst for the theorisation of rival models of intellectual engagement, ${ }^{24}$ the most famous of which was written by Aron's close friend Paul Nizan. In Les chiens de garde, Nizan poured scorn on Benda's rationalist universalism and insisted on the intellectual's responsibility to descend from the ivory tower and support the struggle of the working class. ${ }^{25}$ Raymond Aron had earlier made a minor intervention in the debate provoked by La trahison des clercs, commenting in 1928 that intellectuals should adopt "an attitude of mind that is attached to truth and inspired by generosity, though nonetheless engaged in action". ${ }^{26}$ The subsequent elaboration of his intellectual ethic was entirely consistent with this. Attempting to stake out a position mid-way between the two poles occupied by Benda and Nizan, Aron, like his peers in the GES and GUSDN, sought a "realism" that would take ideas seriously.

As Aron's correspondence with Henry Kissinger shows, this was an enduring preoccupation. Indeed, some commentators regard it as a defining feature of his political 
thought. Daniel J. Mahoney, for instance, has gone so far as to call Aron the twentieth century's "greatest critic of the realist-idealist distinction". ${ }^{27}$ But if this is the case, why did Aron dismiss his earliest political engagements, central to which was the pursuit of a philosophically idealist form of political realism, as irrelevant to his intellectual formation $?^{28}$

Explaining Aron's dismissiveness towards his earliest writings is inevitably a somewhat speculative enterprise, and it must be acknowledged that in many respects his later time in Germany really was a foundational experience. But this is not the whole story. The idea that he too had once been a naïve idealist of the kind that he would spend much of his later career criticising misrepresented Aron's actual politics in the late 1920s, but it was a useful rhetorical device in his polemics against the mainstream French intellectual left. Notwithstanding his post-war reputation as a man of the right, an important element of these polemics throughout Aron's career was his claim of unwavering loyalty to leftwing values. In light of this, Aron may also have glossed over the specifics of his earliest political commitments because the heterodox socialist and radical movements in which he participated as a student were the seedbed for new far right parties that would come to occupy the ultra-collaborationist wing of French politics under the Occupation of 1940-44. Having rejected fascism in the 1930s and denounced intellectual collaborationism in the 1940s, ${ }^{29}$ Aron had nothing to hide on these fronts, but nor was he keen to dwell on the specifics of his early political activism. Nevertheless, the aspiration to combine philosophical idealism with political realism, which he first articulated in the late 1920s, would become a defining feature of Aron's post-war work. And it was in the name of just such a philosophically idealist brand of political realism that Aron challenged Kissinger's conduct during the Cyprus crisis of 1974.

\section{Aron, Kissinger, and the Cyprus crisis of 1974}

On the $15^{\text {th }}$ of July 1974, the democratically elected president of Cyprus, Archbishop Makarios III, narrowly escaped assassination in a coup launched by the American backed Greek military junta in Athens. By overthrowing Makarios, the Greek government wanted to achieve the union of Greece and Cyprus. However, the proclamation that Cyprus would 
henceforth be a Hellenic republic provoked a Turkish invasion of the island that ultimately resulted in its partition and the downfall of the military dictatorship in Greece. The events of 1974 had disastrous consequences for the Greek and Turkish Cypriot communities, thousands of whose members were displaced from their homes as a result of the island's partition. There were also serious geopolitical implications, including the threat of war breaking out between the two NATO member states of Greece and Turkey. And the issue of the United States role in the crisis is particularly controversial. This is partly because Kissinger knew in advance about the coup but did not act to prevent it. The removal of Makarios, whom the Americans saw as a sort of Mediterranean Fidel Castro, was welcome because, to quote Jon Kofas, "Insofar as [he] endeavoured to remain independent and rely on the Kremlin to counterbalance the West, he was a threat to the U.S. policy goal of using Cyprus to buttress NATO's southern flank". ${ }^{30}$ While the coup was widely condemned in the international community, Kissinger pointedly refused either to confirm that the United States still recognised the Makarios government or to deny that the administration would recognise the dictatorship that had replaced it. ${ }^{31}$ To the surprise of many, however, the United States openly backed the initial Turkish invasion, which brought about the downfall of the military dictatorship in Greece, and did not condemn the second invasion, which effectively imposed partition of the island.

Raymond Aron's article on the Cyprus crisis in Le Figaro was critical of Kissinger's role in the affair. He wrote that irrespective of whether the coup against Makarios had originated from Athens, Nicosia or Washington, Kissinger was ultimately responsible because the Greeks would never have launched a putsch unless they believed themselves to have at least tacit American support. Even from a purely cynical perspective, Aron argued, American backing for the coup would only have been justifiable if there was a certainty of Turkish non-intervention. Yet Turkey's response was entirely predictable. In conclusion Aron struck an ironically optimistic note, remarking that at least the crisis in Cyprus, by bringing about the downfall of the Greek military dictatorship, had provided American diplomacy with "an opportunity to act not against the communist danger but in favour of democracy". ${ }^{32}$

After reading this piece Kissinger sent Aron a letter strenuously denying American complicity in any aspect of the crisis. "When this kind of article appears in Le Monde," 
Kissinger remarked, "I let it pass; but when an old friend, whose seriousness, fairness and thoughtfulness I respect beyond anyone else's in Europe, writes in this vein I am bound to react". Kissinger's surprise at his friend's "propagation and perpetuation of myths that undermine the credibility of the United States" is understandable. Aron was, after all, renowned among French journalists for his generally sympathetic coverage of American foreign policy. Yet in his reply to Kissinger Aron was unrepentant.

Did you have to remain silent and give the impression that you did not disapprove of the seizure of power by this gang of suspicious characters? I understand that you tried to avoid the military action of the Turks. But wouldn't you have had a better chance of doing so if you had proclaimed that Makarios remained the legal president? [...] Just as you did not condemn the coup d'état, you did not condemn the second Turkish offensive. The first silence imposed this second one upon you. Yet it is on this point that my criticism was and continues to be based. Must the United States, because of its global responsibilities, never take moral stands, never approve or blame for other than pragmatic reasons? $?^{34}$

Having restated his specific criticism of the United States' role in the recent crisis in Cyprus, Aron went on to develop his larger point about morality in international relations:

[...] I took this opportunity to express a concern that I have felt increasingly for a long time. A dominant power like the United States must also incarnate ideals. And yet, in the Cyprus crisis, what I call the two silences appears to me to be in fundamental contradiction with this realist demand.

\section{Cyprus, Chile, and the ambiguity of Aron's 'morality of prudence'}

Aron's correspondence with Kissinger in the wake of the Cyprus crisis is of interest partly because it at once illustrates and problematizes one of the defining characteristics of his international relations theory. In Peace and War between Nations (1962), Aron theorised 
a "morality of prudence" on the basis of a critique of "realist" and "idealist" visions of international politics. Highly sceptical of the "idealist" notion that inter-state relations could be effectively subjected to the rule of law, Aron self-identified as a "realist" in the field of international relations theory. ${ }^{35}$ Yet he considered that ostensibly "realist" political theories that reduced politics to the pursuit of power as an end in itself and ignored the influence of ideals and values were eminently unrealistic. "Consciousness of reality", as he put it in 1957, "is part of reality". ${ }^{36}$

Aron defined the morality of prudence as "a compromise between rather than a synthesis of the morality of struggle and the morality of law". ${ }^{37} \mathrm{He}$ described this as an approach that "attempts not only to consider each case in its concrete particularities, but also not to ignore any of the arguments of principle and opportunity, to forget neither the relation of forces nor the wills of peoples." ${ }^{38}$ Such an approach, he continued, "does not resolve the antinomies of strategic-diplomatic conduct, but it does attempt to find in each case the most accessible compromise". ${ }^{39}$ The problem with this aspect of his theory of international relations, however, was that it provided no means of determining how to strike the balance between moral and power political considerations other than this injunction to seek "the most accessible compromise" by "consider[ing] each case in its concrete particularities". ${ }^{40}$

A comparison of the different responses that Aron gave to the crisis in Cyprus and the coup against Salvador Allende in Chile the previous September gives some indication of where he drew the line in terms of deciding when publicly to criticise the more controversial aspects of American foreign policy. Before turning to this comparison, however, it is worth briefly considering how Aron viewed the question of whether or not the United States should interfere in the internal politics of other countries when he approached this issue in the abstract. In Peace and War between Nations, Aron was very clear that "Within a heterogeneous system, every ruling power is obliged to exercise an influence on the internal affairs of secondary states, at least to the degree necessary to prevent the victory of the party linked to the rival camp" ${ }^{41}$ However, he went on to remark that 
[I]t is not impossible to convince American strategists first and foremost that no regime - whatever its institutions - need be called Communist as long as a party owing allegiance to Moscow is not in power. Next they must be convinced that even a regime in which the Communist party is in power, in Africa or in Latin America, is not the same as a regime imposed upon a country of Eastern Europe by the Red Army [...] instead of acting and above all talking as if our security were endangered each time 'Ruritania' declares its allegiance to Moscow, it would be better to show detachment and a certain indifference $[\ldots]^{42}$

Although the subsequent development of US foreign policy did not exactly follow this blueprint, in The Imperial Republic (1973), a study of post-war American foreign policy, Aron remarked hopefully upon an apparent "shift from activism to abstention" since start of the Nixon presidency. Aron credited the Nixon administration with "a less active interest and less intolerance of revolutionary regimes, even those prone to use socialist or even Marxist-Leninist language". By way of illustration he then wrote that "Washington apparently did not mobilise either the CIA or its friends against the nationalist military government in Peru or against Allende's experiment in Chile". ${ }^{43}$

These remarks were written at some point between September and November 1973. As such it is possible that Aron wrote them before the 11 September coup that overthrew Salvador Allende's government in Chile. Even if this were the case, however, it is highly unlikely that the issue of American interference had not occurred to Aron because the CIA's involvement in efforts to prevent the election of Allende in 1970 had already come to light in March 1972. Because of this, the likelihood of American involvement in the coup of 1973 was immediately discussed in the earliest French press coverage of Allende's downfall. ${ }^{44}$ Yet Aron's first article on this subject, which appeared in Le Figaro on 14 September, made no mention of the United States and downplayed the political implications of Allende's removal from power:

There is nothing that I detest more than military coups, even those which circumstances and artifice allow to be concealed under the appearance of 
legality. But what the commentator cannot and must not forget is that in September 1973 the Chilean army seemed respectful of institutions, that it indeed was so during the first two years of the popular unity regime, that it even saved president Allende when several military leaders agreed to enter the government. The army ultimately broke with its tradition and principles only at the point when the failure of president Allende was complete. It intervened not to arrest the progress of socialism [...] but to prevent a civil war. ${ }^{45}$

Although he did not mention the issue of American interference in his newspaper commentary on the Chilean coup, Aron did raise this in his private correspondence with Kissinger following the Cyrus crisis. Here he wrote that:

When we were both professors, we used to discuss the difficulty of drawing the line between realism and cynicism. You have bigger fish to fry than to philosophise. But like me you believe that creative action at a certain level is inseparable from a philosophy. The combination of rapprochement with the Soviet Union and America's funding of Allende's adversaries creates a nagging sense of doubt among the United States' best friends. ${ }^{46}$

In his letter to Kissinger concerning the crisis in Cyprus Aron explained that he "took this opportunity to express a concern that I have felt increasingly for a long time", suggesting that his private concerns about American policy in Chile informed his decision publicly to criticise the United States over its role in the confrontation between Greece and Turkey over Cyprus. But had the two crises occurred in reverse order, it seems unlikely that Aron would have covered events in Chile very differently.

As a staunch Atlanticist, Aron's commentary on international politics was generally informed by a desire to avoid undermining the United States, but this did not rule out criticism of American foreign policy altogether, especially when the United States' actions seriously threatened the cohesion of the Atlantic alliance. From this perspective, the stakes of the Cyprus crisis were much higher than those of the Chilean coup because in Cyprus 
there was a real danger of war breaking out between two NATO member states. In these circumstances Aron was willing to risk "undermining the credibility of the United States" as Kissinger put it. That he was less willing to do this in the Chilean case probably also reflected the greater resonance of that case with domestic French politics, where supporters of the electoral coalition recently established between the French Socialist and Communist parties were quick to draw parallels between Chile's Popular Unity government and the French Union of the Left.

Of perhaps greater interest than Aron's ultimately unsurprising silence on the question of American interference in Chilean politics is the significance of his Figaro article in relation to Aron's views on recent French political history. Although he was renowned as one of France's most well-informed political commentators, by his own admission Aron was less than an expert on contemporary Latin America. Consequently, like many other French commentators at the time, his interpretation of events in Chile was informed by his understanding of comparable episodes in recent French history. As his remark about the abhorrence even of quasi-legal military coups indicates, Charles de Gaulle's controversial return to power during the Algerian War in 1958 was one point of reference for his understanding of events in Chile. Another common point of reference among French commentators on the political crisis in Chile was the Popular Front and its political nemesis, the Vichy dictatorship of 1940-44. Here too it is likely that Aron's understanding of the Chilean present was informed by his memory of the French past.

\section{The Chilean coup in light of France's interwar crisis of democracy}

In 1969 Aron wrote that "Over the course of the 1930s I observed, almost despairingly, the decadence of the French nation and the corruption of democracies; I sometimes wondered if it would one day be necessary to choose between the salvation of the fatherland and the safeguarding of liberty". ${ }^{47}$ This was a theme to which Aron would return in more detail as he neared the end of his life. In his memoirs he wrote that that before the war "I occasionally found myself thinking, and perhaps saying aloud: if an authoritarian regime is necessary to save France, so be it; let us accept it, while simultaneously detesting it". ${ }^{48}$ 
It is most likely that these thoughts occurred to Aron in the period between the end of the first Popular Front government in 1937 and the beginning of the Daladier administration, which, governing by decree between April 1938 and March 1940, effectively established what has retrospectively been called "the authoritarian Republic". 49 In February 1937 Aron first raised this issue in writing at the conclusion of a highly critical article on the Popular Front, which argued that French democracy was facing a moment of truth: "Will France continue to slide down the path that, from demagogy to anarchy, leads to degeneration, or will it succeed, by constitutional means or by a revolution, in restoring a strong authority? Who will have this authority?"50 By this point Aron's friends from his time in the GUSDN, Bertrand de Jouvenel and Alfred Fabre-Luce, had both joined Jacques Doriot's fascist Parti Populaire Français. Although Aron deplored his friends' decision to support the PPF, an organisation which he considered to have exacerbated French decadence by further intensifying the polarisation of national politics, in July 1938 he wrote to Fabre-Luce that he agreed with "at least $75 \%$ " of his critique of republican democracy. ${ }^{51}$ Since the objection that Aron raised against the PPF applied equally to a second mass party of the far right, the Parti Social Français, the most obvious remaining authoritarian option conceivably available at the time would have been a government of public safety under the leadership of Marshal Philippe Pétain.

In 1935 Pétain had come at the top of a poll organised by Le Petit Journal to discover who would be the most popular prospective French dictator. ${ }^{52}$ The Marshal was less open to the objection that Aron raised against the PPF because, as a widely revered war hero and a reputedly good republican, he held a potentially much broader appeal among the French public. Therefore if there was a specific authoritarian solution to the crisis of French democracy that Aron was prepared to contemplate in 1937-8, then a Pétainist dictatorship is the most likely option. To be clear, this was not a prospect that he envisaged with any degree of enthusiasm; in no way was Aron a proponent of authoritarianism for its own sake. But for Aron there was something worse than the denial of public liberties that a dictatorship would obviously entail, and that was the prospect of civil war. ${ }^{53}$

As he repeatedly stressed in his recollections of this period toward the end of his life, the need to avoid civil war was the issue that obsessed Aron above all others in the 
mid-to-late 1930s. ${ }^{54}$ If his Atlanticist reluctance to join the chorus of condemnation relating to American involvement in the coup against Allende informed his initial public silence on this issue, his rather generous interpretation of the Chilean military's intentions in removing Allende from power was more likely to have been informed by his recollections of the interwar crisis of French democracy.

\section{Conclusion}

France in the mid-1930s may not be an obvious lens through which to interpret Aron's response to events in Chile during the mid-1970s; however, this proposition is not as farfetched as it might seem. By the middle of the 1970s, debates over the memory of France's "dark years" between 1934 and 1944 were entering what has been called an "obsessional" phase. ${ }^{55}$ At the same time, Aron had begun to write down his own reminiscences of this period in a process that would culminate with the publication of his memoirs in 1983. The fact that this coincided with rising controversy over the question of French immunity or susceptibility to fascism in the interwar period inevitably shaped the way that Aron presented his own intellectual and political development when discussing this period in the 1970s and early 1980s. To be very clear, this is not to suggest that the young Aron harboured crypto-fascist tendencies which he later tried to obscure. But the fact that he received his earliest political socialisation in the same milieux from which a form of French fascism did eventually emerge in the 1930s should be taken into account when evaluating Aron's tendency to dismiss the significance of the political views that he held before 1933. This is important not only so as to arrive at a fuller understanding of Aron's early political and intellectual trajectory, but also to achieve a more comprehensive view of the origins of his intellectual ethic and philosophically idealist brand of political realism.

Aron's correspondence with Kissinger at once illustrates and problematizes these characteristics of this political thought. One of the obvious objections to his view that intellectuals had a duty to evaluate politics from the statesman's perspective is that it excessively narrows the scope for serious, independent criticism of government, reducing political commentary to a sort of technical amorality. In the face of such objections, it is

possible to see Aron's response to the Cyprus crisis as a vindication of his intellectual ethic. 
Aron believed intellectuals commenting on politics had a responsibility to do so from the perspective of the statesman. But he also thought that statesmen had a responsibility to take values and ideals seriously. Thus while it is true that Aron's entire public persona was built on an explicit refusal to "act as the interpreter of the universal moral conscience", 56 this rejection of moralism was not a repudiation of morality as such. Indeed, as his correspondence with Kissinger makes clear, Aron thought that moral considerations could not be evacuated from authentically realist political calculation. Although he arguably could offer no satisfactory means of arbitrating between the demands of morality and politics, this was a problem with which Aron had wrestled from significantly earlier in his life than is generally acknowledged.

\footnotetext{
${ }^{1}$ Henry Kissinger, 'My teacher', Commentaire 28 (1984), 129. In his foreword to the abridged English translation of Aron's memoirs Kissinger later wrote that "Raymond Aron was my friend. He was also my teacher. Few intellectuals have had a deeper impact on my thinking; none a greater one. Lest I burden his memory with my critics, let me add that he was on occasion less than satisfied with his student". Henry Kissinger, 'Foreword', in Raymond Aron, Memoirs: Fifty Years of Political Thought, trans. George Holoch (New York: Holmes \& Meier, 1990), ix. I am grateful to Henry Kissinger for his permission to quote from his private correspondence with Aron. I am also grateful to Daniel Steinmetz-Jenkins and Stephen W. Sawyer for their invitation to contribute to this issue and their feedback on an earlier draft of this article.

${ }^{2}$ Letter from Henry Kissinger to Raymond Aron, 22 December 1966 in Fonds Raymond Aron, Bibliothèque Nationale de France, NAF28060(207).

${ }^{3}$ Henry Kissinger, 'Fuller explanation', New York Times, 12 February 1967.

${ }^{4}$ Letter from Henry Kissinger to Raymond Aron, 10 June 1970 in Fonds Raymond Aron, Bibliothèque Nationale de France, NAF28060(207).

${ }^{5}$ Although this issue is relevant to recent efforts to recast Kissinger as an idealist, the significance of the correspondence in relation to Aronian political realism will be my main concern in the present article. On Kissinger as idealist see Niall Ferguson, Kissinger, 1923-1968: The Idealist (London: Allen Lane, 2015). ${ }^{6}$ Raymond Aron, Thinking Politically: A Liberal in the Age of Ideology, 154. Daniel J. Mahoney and Brian C. Anderson both quote this passage to elucidate their view of Aron as an authentically political thinker. See Mahoney, The Liberal Political Science of Raymond Aron, 14; Brian C. Anderson, Raymond Aron: The Recovery of the Political (Lanham: Rowman \& Littlefield, 1997), 4.

${ }^{7}$ Aron, Le spectateur engagé, 43.

${ }^{8}$ Daniel J. Mahoney, The Liberal Political Science of Raymond Aron (Lanham: Rowman \& Littlefield, 1992), 105-6; Brian C. Anderson, Raymond Aron: The Recovery of the Political (Lanham: Rowman \& Littlefield, 1997), 3-4; Aurelian Craiutu, Faces of Moderation: The Art of Balance in an Age of Extremes (Philadelphia: University of Pennsylvania Press, 2017), 34-70, 35.

${ }^{9}$ Baverez, Raymond Aron, 89.

${ }^{10}$ Aurelian Craiutu, Faces of Moderation: The Art of Balance in an Age of Extremes (Philadelphia: University of Pennsylvania Press, 2017), 34-70, 35.

${ }^{11}$ Craiutu, Faces of Moderation, 44, 46.

Raymond Aron, 'Lettre ouverte d'un jeune français à l'Allemagne', Esprit, 1 (février, 1933), 735-743, 735, 742 .

${ }^{13}$ Aron, Mémoires: 50 ans de réflexion politique (Paris: Julliard, 1983), 79-80.

${ }^{14}$ Jean-François Sirinelli, Génération intellectuel: khâgneux et normaliens dans l'entre-deux-guerres (Paris, 1988), 427-96.

${ }^{15}$ Raymond Aron, 'Réflexions sur le pacifisme intégral', Libres Propos (février 1933), 96-99; Raymond Aron, 'Philosophie de pacifisme' [1941] in Raymond Aron, L'homme contre les tyrans (New York: Éditions de la Maison Française, 1944), 111-127, 124-127; Raymond Aron, 'Alain et la politique' [1952] in
} 
Raymond Aron, Études politiques (Paris: Gallimard, 1972), 75-84, 81-83. See also Raymond Aron, Les étapes de la pensée sociologique (Paris, 1967), 525-529. During his years at the École normale, Aron had been a peripheral member of Alain's coterie of young admirers - see Sirinelli, Génération, 427-496. ${ }^{16}$ Raymond Aron, 'Réflexions sur les problèmes économiques français', Revue de métaphysique et de morale XLIV (November, 1937), 793-822, 793.

${ }^{17}$ Alain, Le citoyen contre les pouvoirs (Paris: Éditions du Sagittaire, 1926), 143; Aron, 'Réflexions sur les problèmes économiques français', 793-795.

${ }^{18}$ This term was first used with reference to Aron in Allan Bloom, 'Le dernier des libéraux', Commentaire 28-29 (1985), 174-81, 174. It is also frequently applied in Daniel J. Mahoney, The Liberal Political Science of Raymond Aron, ix, xii, 9, 14-16, 43, 46, 49, 76, 78, 88-89, 111, 138.

${ }^{19}$ Stephane Clouet, De la renovation à l'utopie socialistes: Révolution Constructive, un groupe d'intellectuels socialistes des années 1930 (Nancy: Presses Universitaires de Nancy, 1991), 54; Jean-

François Biard, Le Socislisme devant ses choix: La naissance de l'idée de plan (Paris: Publications de la Sorbonne, 1985), 93-94; Olivier Dard, Le rendez-vous manqué des relèves des années 30 (Paris: PUF, 2002), 57-59. For a contemporary perspective see e.g. Marcel Déat, Perspectives Socialistes (Paris: Librairie Valois, 1930), 9-10.

${ }^{20}$ Jean Luchaire, Une génération réaliste (Paris: Valois, 1929), 44, 132-37.

${ }^{21}$ Raymond Aron, 'Ce que pense la jeunesse universitaire d'Europe,' Revue de Genève (December 1926), 789-94, 791-92. The C.A.P., or Comité Administratif Permanent, was the SFIO's governing committee, a notoriously bureaucratic and hidebound organisation. I am indebted to Grey Anderson, David C. Wright and David Slavin for their assistance in identifying the meaning of this abbreviation.

${ }^{22}$ Raymond Aron, 'Lettre ouverte d'un jeune français à l'Allemagne', Esprit, 1 (février, 1933), 735-743, 743.

${ }^{23}$ Julien Benda, La trahison des clercs (Paris: Bernard Grasset, 1927), 46-52.

${ }^{24}$ Martin Cornick, 'Catalyst for intellectual engagement: the serialisation of Julien Benda's La trahison des clercs in the Nouvelle Revue Française', French Cultural Studies, IV (1993), 31-49.

${ }^{25}$ Paul Nizan, Les chiens de garde (Paris, 1932), 11-12, 19-28, 37.

${ }^{26}$ Raymond Aron, 'A propos de la trahison des clercs', Libres Propos, vol 2, no. 4 (April 1928), 176-178, 178.

${ }^{27}$ Mahoney, The Liberal Political Science of Raymond Aron, 95.

${ }^{28}$ Raymond Aron, Le spectateur engagé, (Paris, 1981), 28

${ }^{29}$ Raymond Aron, L'homme contre les tyrans (New York: Éditions de la Maison Française, 1944), 171223.

${ }^{30}$ Kofas, Under the Eagle's Claw, 129.

${ }^{31}$ Christopher Hitchens, The Trial of Henry Kissinger (London: Atlantic Books, 2012), 114.

${ }^{32}$ Raymond Aron, 'Les pièges du destin', Le Figaro, 29 August 1974.

${ }^{33}$ Letter from Henry Kissinger to Raymond Aron, 7 September 1974 in Fonds Raymond Aron, Bibliothèque Nationale de France, NAF28060(207).

${ }^{34}$ Letter from Raymond Aron to Henry Kissinger, 19 September 1974 in Fonds Raymond Aron, Bibliothèque Nationale de France, NAF28060(207).

${ }^{35}$ Raymond Aron, The Imperial Republic: The United States and the World, 1945-1973 (London:

Weidenfeld and Nicolson, 1974), xviii.

${ }^{36}$ Raymond Aron, Démocratie et totalitarisme (Paris: Gallimard, 1965), 4.

${ }^{37}$ Aron, Peace and War between Nations, 611.

${ }^{38}$ Aron, Peace and War between Nations, 609.

${ }^{39}$ Raymond Aron, Peace and War between Nations, 609.

${ }^{40}$ Raymond Aron, Peace and War between Nations, 609.

${ }^{41}$ Aron, Peace and War, 260. See also page 730: "What occurs within one of the member states of an international society cannot be a matter of indifference to the other members of that society. The latter declare themselves indifferent when the changes of regime and government do not substantially modify the international actor and the rules of the game, hence when the system is homogeneous. They cannot pretend to indifference when the substitution of one regime for another involves a change of sides. [...] Peace between states, in a heterogeneous system, excludes the implicit agreement of sovereigns against rebels and heretics, since the heretics of one bloc are the believers of the other. Peace would therefore require, at minimum, reciprocal abstention, but the latter, in its turn, is forbidden by the technological unification of the world and the universal vocation of ideologies in our century". 
${ }^{42}$ Aron, Peace and War, 696.

${ }^{43}$ Aron, The Imperial Republic, 140-1.

${ }^{44}$ See e.g. 'L'I.T.T., "État souverain"” and 'Washington: satisfaction embarrassée' in Le Monde 13 September 1973.

${ }^{45}$ Raymond Aron, 'La tragédie chilienne', Le Figaro, 14 September 1973.

${ }^{46}$ Aron to Kissinger, 19 September 1974.

${ }^{47}$ Raymond Aron, Marxismes imaginaires: d'une sainte famille à l'autre (Paris: Gallimard, 1970).

${ }^{48}$ Aron, Mémoires, 151.

49 Julian Jackson, France: The Dark Years (Oxford: Oxford University Press, 2001), 102-4.

${ }^{50}$ Raymond Aron, 'Réflexions sur les problèmes économiques français', Revue de métaphysique et de morale XLIV (November, 1937), 793-822, 815.

${ }^{51}$ Letter from Raymond Aron to Alfred Fabre-Luce, 24 July 1938, Fonds Raymond Aron, Bibliothèque nationale de France NAF28060(206).

${ }^{52}$ Jackson, France: The Dark Years, 124.

${ }^{53}$ It is also worth noting that Aron was an admirer of Carl Schmitt's writings on the state of exception, which were pertinent both to his understanding of French politics in the late 1930s and his analysis of the Chilean coup in 1973. The year before this coup Aron had overseen the publication of the first French translation of Schmitt's writing on this theme. See Carl Schmitt, La notion de politique (Paris: CalmannLévy, 1972). On Aron's relationship with Schmitt and his acolytes see Daniel Steinmentz-Jenkins, 'Why did Raymond Aron write that Carl Schmitt was not a Nazi? An alternative genealogy of French liberalism', Modern Intellectual History, 11(November, 2014), 549-74.

${ }_{54}^{54}$ Aron, Le spectateur engagé, 44-49, 69-75; Aron, Mémoires, 151.

${ }^{55}$ Henry Rousso, The Vichy Syndrome: History and Memory in France since 1944, trans. Arthur Goldhammer (Cambridge MA: Harvard University Press, 1991), 132-67.

${ }^{56}$ Aron, The Imperial Republic, xix. 